\title{
PRESENCE OF ECOTOXICOLOGICALLY RELEVANT Pgp AND MRP TRANSCRIPTS AND PROTEINS IN CYPRINID FISH
}

\author{
Roberta SAUERBORN KLOBUČAR ${ }^{1}$, Roko ŽAJA ${ }^{1}$, Damjan FRANJEVIĆ ${ }^{2}$, Anamaria \\ BROZOVIĆ ${ }^{3}$, and Trrtko SMITAL ${ }^{1}$
}

Division for Marine and Environmental Research, Ruđer Bošković Institute ${ }^{1}$, Division of Biology, Faculty of Science, University of Zagreb², Division for Molecular Biology, Ruđer Bošković Institute, Zagreb, Croatia

Received in October 2009

Accepted in March 2010

\begin{abstract}
One of the most intriguing defence strategies which aquatic organisms developed through evolution is multixenobiotic resistance (MXR). The key mediators of MXR activity are ATP-binding cassette (ABC) transport proteins. They provide resistance of aquatic organisms by binding xenobiotics and extruding them from cells in an energy-dependent manner. Since Cyprinid fish species are common target in freshwater biomonitoring programs, we have studied the presence of two main MDR/MXR efflux transporters Pglycoprotein (Pgp, Abcb1) and MRP-like protein(s) (Abcc) in the liver of five Cyprinid species: common carp, European chub, sneep, barbel, and silver prussian carp. Their presence was evaluated on the mRNA and protein level. Various pairs of primers were designed to clone homologous fragments of MXR-related genes. At the protein level, we used Western blotting with specific monoclonal antibodies against human Pgp (Abcb1, Ab C219), MRP1 (Abcc1; Ab MRPm6) or MRP2 (Abcc2; Ab M2I-4). Transcripts of both key types of MXR transporters were identified in all species examined and here we provide the phylogenetic analysis of new partial sequences. Immunochemical determinations with mammalian antibodies failed to identify the presence of MRP(s), but Pgp expression was found in all five Cyprinid species. These results support that MXR is a defence system mediated by both Pgp and MRP types of ABC transport proteins.
\end{abstract}

KEY WORDS: $A B C$ proteins, aquatic organisms, multixenobiotic resistance, $M X R$, phylogenetic analysis, Western blot analysis

Multidrug resistance (MDR) phenotype in mammals can arise as a result of different molecular mechanisms such as induction of detoxifying enzymes, subcellular redistribution of drugs into lysosomes, differential expression of topoisomerase II $\alpha$, or ATPbinding cassette $(\mathrm{ABC})$ transporters-mediated drug efflux $(1,2)$. The most studied MDR mechanism is the enhanced ability $\mathrm{ABC}$ transport proteins to actively efflux drugs leading to lower concentration inside the cells (3).

Among them, P-glycoprotein (MDR1, Pgp, $A B C B 1)$ has been the first and best characterised $A B C$ transporter due to its overexpression in various tumour tissues and cell lines. Furthermore, the presence and function of P-glycoprotein has been reported in almost 40 aquatic organisms investigated so far (4). As a specific transmembrane efflux transporter that pumps structurally different xenobiotics out of the cell, in Pgp (Abcb1) appeared to be the key mediator of the so-called multixenobiotic resistance (MXR) defence system $(5,6)$ in aquatic organisms. It has been shown that the MXR phenomenon is constitutive to aquatic organisms, inducible in response to pollution (7-9), and sensitive to specific environmental pollutants/ 
chemicals of both natural and anthropogenic origin, commonly called MXR inhibitors or chemosensitisers $(10,11)$. However, the recent discovery of non-Pgp efflux transporters in various mammalian tissues implies that MXR in aquatic biota may also be a multi-transporter mechanism. Among non-Pgp ABC proteins, members of a multidrug resistance-associated protein (MRP) subfamily ABCC have been shown to be toxicologically relevant (12-14). Our earlier studies (15-17) and studies of other groups recently demonstrated the expression of MRP-related genes in a number of fish and invertebrate species (18-20).

The primary goal of this study was to determine Pgp (Abcb1) and Mrp (Abcc) related mRNA transcripts in a group of freshwater cyprinidae, as follows: common carp (Cyprinus carpio), European chub (Squalius cephalus), sneep (Chondrostoma nasus), barbel (Barbus barbus), and silver Prussian carp (Carassius auratus gibelio). These species are typical representatives of the fish communities of continental European waters and are frequently used in biomonitoring programmes/studies $(21,22)$. Additionally, we tried to detect Pgp and MRPs on the protein level using commercially available antibodies directed against human Pgp and MRP(s).

Identified sequences share a high degree of homology with the P-glycoprotein (Pgp, Abcb1), Mrp1 (Abcc1), Mrp2 (Abcc2), and Mrp3 (Abcc3) proteins, while phylogenetic analysis shows grouping of identified sequences within $\mathrm{ABCB}$ and $\mathrm{ABCC}$ subfamily of other organisms.

\section{MATERIALS AND METHODS}

\section{Animals}

Chub, sneep, barbel, and silver Prussian carp specimens were collected by electrofishing from the Sava River (Croatia), while common carp was provided by a local fish farm.

\section{Detection of Pgp and Mrp related $m R N A$ transcripts in fish liver}

Primer pairs (Table 1) were designed from highly conserved regions of mammalian and fish $\mathrm{ABCB} 1$ and $\mathrm{ABCC} 1 / 2$ genes and obtained from Operon Biotechnologies (Köln, Germany) or Invitrogen (Carlsbad, CA, USA).

Total RNA was extracted from liver tissue using the Agilent Total RNA Isolation Mini Kit (Agilent Technologies, Palo Alto, CA, USA). The quality of RNA samples was analysed using an RNA 6000 Nano LabChip Kit (Agilent Technologies). Three micrograms of total RNA were then reverse transcribed using M-MuLV reverse transcriptase according to manufacturer's instructions (RevertAid First Strand cDNA synthesis Kit, Fermentas, Ontario, Canada). Polymerase chain reaction (PCR) was performed in Biometra thermal Cycler (Goettingen, Germany) with $3 \mu \mathrm{L}$ of cDNA in a total volume of $50 \mu \mathrm{L}$. The cycling parameters were as follows: denaturation at $94{ }^{\circ} \mathrm{C}$ for $2 \mathrm{~min}, 35$ cycles of heat denaturation at $94{ }^{\circ} \mathrm{C}$ for $30 \mathrm{~s}$, annealing at $54{ }^{\circ} \mathrm{C}$ for $30 \mathrm{~s}$, polymerisation at $72{ }^{\circ} \mathrm{C}$ for

Table 1 Primers used for PCR amplification of cDNA corresponding to Pgp (Abcb1) and Mrp (Abcc)-related genes

\begin{tabular}{|c|c|c|c|c|c|}
\hline $\begin{array}{l}\text { PRIMER } \\
\text { PAIR }\end{array}$ & & $5^{\prime} \rightarrow 3^{\prime}$ & FISH & $\begin{array}{l}\text { TARGETED } \\
\text { GENE }\end{array}$ & $\begin{array}{l}\text { IDENTIF. } \\
\text { GENE }\end{array}$ \\
\hline $\mathrm{A} / \mathrm{B}$ & $\begin{array}{l}\mathrm{F} \\
\mathrm{R}\end{array}$ & $\begin{array}{l}\text { GCG GCT GTG GGA AGA GCA C } \\
\text { TGT TGT CTC CGT AGG CAA TGT T }\end{array}$ & All fishes & $\begin{array}{c}\text { Pgp } \\
(\text { Abcb1) }\end{array}$ & Abcb1 \\
\hline $\mathrm{C} / \mathrm{D}$ & $\begin{array}{l}\mathrm{F} \\
\mathrm{R}\end{array}$ & $\begin{array}{l}\text { ACCGAGATCGGAGAGAAGG } \\
\text { CTG TCC AGG ATG GTG TTG A }\end{array}$ & $\begin{array}{l}\text { Chub } \\
\text { Prussian carp }\end{array}$ & \multirow{3}{*}{$\begin{array}{c}\operatorname{Mrp} 1 / 2 \\
(\mathrm{Abcc1} 1 / 2)\end{array}$} & Abcc2 \\
\hline $\mathrm{E} / \mathrm{F}$ & $\begin{array}{l}\mathrm{F} \\
\mathrm{R}\end{array}$ & $\begin{array}{l}\text { GGTGGAGGCCTGTGCTCT } \\
\text { CTG TCC AGG ATG GTG TTG A }\end{array}$ & $\begin{array}{l}\text { Common carp } \\
\text { Barbel }\end{array}$ & & $\begin{array}{l}\text { Abcc3 } \\
\text { Abcc1 }\end{array}$ \\
\hline $\mathrm{G} / \mathrm{H}$ & $\begin{array}{l}\mathrm{F} \\
\mathrm{R}\end{array}$ & $\begin{array}{l}\text { AAT GAC ACC ATA CAG GAC AAC ATC } \\
\text { CA TCC ACT GCA GAC AGG GGG TC }\end{array}$ & Sneep & & Abcc2 \\
\hline
\end{tabular}


$30 \mathrm{~s}$, and final extension at $72^{\circ} \mathrm{C}$ for $7 \mathrm{~min}$. Aliquots of each reaction were resolved by electrophoresis on $1.2 \%$ agarose gel in the TAE buffer, the gels were stained with ethidium bromide and PCR products visualised under UV light. The expected amplimers obtained from all cyprinid species were excised and eluted using MiniElute PCR Purification Kit (Qiagen, Hilden, Germany). Isolated cDNAs of less than 1,000 bp size were sequenced directly, while longer cDNAs were subcloned into a suitable plasmid vector and transformed into Escherichia coli (PCR Cloning Kit, Qiagen). Plasmids were isolated from overnight cultures of transformants using QIAprep Miniprep (Qiagen). cDNAs were sequenced on both strands by VBC-Genomics (Vienna, Austria).

\section{Fish tissue collection and Western blot analysis}

Within three hours after catch, fish were killed and livers dissected and stored in liquid nitrogen. Membrane vesicles were prepared as described by Cornwell et al. (23). Phenylmethanesulfonylfluoride (PMSF) serine protease inhibitor was substituted with a protease inhibitor cocktail (Sigma, St Louis, MO, USA). Membrane vesicle proteins were resolved on a $7.5 \%$ acrylamide gel at a constant voltage of $200 \mathrm{~V}$ in BioRad Mini-PROTEAN 3 Cell system; 25 mmol L-1 Tris-HCl, pH 8.3, $192 \mathrm{mmol} \mathrm{L}^{-1}$ glycine, and $0.1 \%$ SDS running buffer. Electrophoretic transfer to Immobilon-P membrane (Millipore, Schwalbach, Germany) in BioRad Mini Trans-Blot followed the manufacturer's recommendations. The blots were blocked with $3 \%$ bovine serum albumin (BSA,fraction V) in $20 \mathrm{mmol} \mathrm{L}^{-1}$ Tris, $\mathrm{pH}$ 7.5, $500 \mathrm{mmol} \mathrm{L}^{-1} \mathrm{NaCl}, 0.05 \%$ Tween-20 (TTBS) solution for $3 \mathrm{~h}$ at room temperature. Membranes were then incubated overnight with mammalian C219 (1:1000), MRPm6 (1:50), and $\mathrm{M}_{2} \mathrm{I}-4$ (1:50) monoclonal antibodies (Signet Laboratories, Dedham, MA, USA) in antibody buffer (1 \% BSA in TTBS), followed by three 5-min washes in TTBS, and a 60-min conjugate binding with a 1:3,000 solution of Goat Anti-mouse IgG horseradish peroxidase (GAM-HRP)conjugate (BioRad Laboratories, Hercules, CA, USA) in antibody buffer. Following TTBS and tris buffered saline (TBS) washes, immunoreactivity was detected using Opti-4CN Substrate Kit (BioRad, USA). Protein Ladder $11 \mathrm{kDa}$ to $170 \mathrm{kDa}$ (Fermentas, Canada) was used for molecular weight determination.

\section{Phylogenetic analysis}

All sequences were aligned using Clustal X software (24) and then adjusted by eye. The alignments were trimmed at the ends with BioEdit 7.0.5.2 to avoid inclusion of missing data (25). Phylogenetic relationships were estimated against two optimality criteria, maximum likelihood (ML) and neighbour joining (NJ) using a software program PAUP* version $4.0 \mathrm{~b} 10$ (26). The ML starting tree was obtained via stepwise addition and replicated 100 times, with each replicate starting with a random input order of sequences. Global alignment and lookout for similar sequences were done using the BLAST Internet service (27).

Table 2 List of all identified Pgp (Abcb1) and Mrp (Abcc)-related mRNA sequences in cyprinid fish species with the length of sequences

\begin{tabular}{lcc}
\hline ORGANISM & $\begin{array}{c}\text { Pgp (Accession number) } \\
\text { Sequence length }\end{array}$ & $\begin{array}{c}\text { Mrp (Accession number) } \\
\text { Sequence length }\end{array}$ \\
\hline Common carp & AY999964 & FJ890347 \\
$($ C.carpio $)$ & $198 \mathrm{bp}$ & $1425 \mathrm{bp}$ \\
\hline Barbel & $\mathrm{DQ} 059069$ & $\mathrm{FJ} 890350$ \\
$($ B.barbus $)$ & $197 \mathrm{bp}$ & $2091 \mathrm{bp}$ \\
\hline Chub & $\mathrm{AY} 999966$ & $\mathrm{FJ} 890348$ \\
$($ S.cephalus $)$ & $197 \mathrm{bp}$ & $2136 \mathrm{bp}$ \\
\hline Sneep & $\mathrm{AY} 948951$ & $\mathrm{AY} 948950$ \\
$($ C.nasus $)$ & $167 \mathrm{bp}$ & $120 \mathrm{bp}$ \\
\hline Prussian carp & $\mathrm{DQ} 059072$ & FJ890349 \\
$($ C.auratus gibelio $)$ & $197 \mathrm{bp}$ & $1431 \mathrm{bp}$ \\
\hline
\end{tabular}




\section{RESULTS AND DISCUSSION}

\section{Detection of Pgp (Abcb1) and MRP (Abcc)-related sequences}

Based on known full and/or partial Pgp (Abcb1) and MRP1/2 (Abcc1/2) sequences from vertebrate and invertebrate species, we designed specific pairs of primers (Table 1). Using the primer pair A/B, designed to detect the Pgp transcript, we obtained a fragment of $199 \mathrm{bp}$ in length in all target cyprinids. Amplification with $\mathrm{C} / \mathrm{D}$ and $\mathrm{E} / \mathrm{F}$ MRP specific primer pairs resulted in over 2,000 bp fragments in all cyprinids except sneep. For sneep we obtained only a short $120 \mathrm{bp}$ fragment with the $\mathrm{G} / \mathrm{H}$ primer pair.

After cloning, sequencing, and computer-based sequence analysis using BLAST (NCBI), we confirmed high sequence homology at Pgp/MRP gene and protein level with other species. The obtained sequence data were submitted to the GenBank database. Identified partial Pgp mRNA sequences were registered with following accession numbers: common carp-AY999964, chub-AY999966, sneepAY948951, barbel-DQ059069, silver prussian carpDQ059072. MRP sequence corresponded to Mrp1
(Abcc1) - barbel, Mrp2 (Abcc2) - chub and Prussian carp, and Mrp3 (Abcc3) - common carp. The related accession numbers are common carp-FJ890347, chubFJ890348, sneep-AY948950, barbel-FJ890350, and silver prussian carp-FJ890349 (Table 2).

Multiple alignments of Pgp sequences are shown in Figure 1. These sequences are homologous to Pgp genes from other organisms and share a high degree of homology with other fish and mammals (76\% to $96 \%$ ). The figure shows which nucleotides are the most conserved between different taxonomic groups.

The obtained homologies for the predicted Mrp peptide sequences among target fish species were in the range of $80 \%$ to $95 \%$ for Mrp1 (Abcc1; barbel), $73 \%$ to $96 \%$ for Mrp2 (Abcc2; chub and Prussian carp), and $80 \%$ to $95 \%$ for Mrp3 (Abcc3; common carp).

It was interesting to note that use of the same pair of primers resulted in fragments related to two different genes: Mrp1 (in barbel) and Mrp3 (in common carp) (Table 1). Based on these data we assume that both mRNA transcripts are present in fish liver cells and analysis of more clones could have probably resulted in the identification of both genes in each organism.
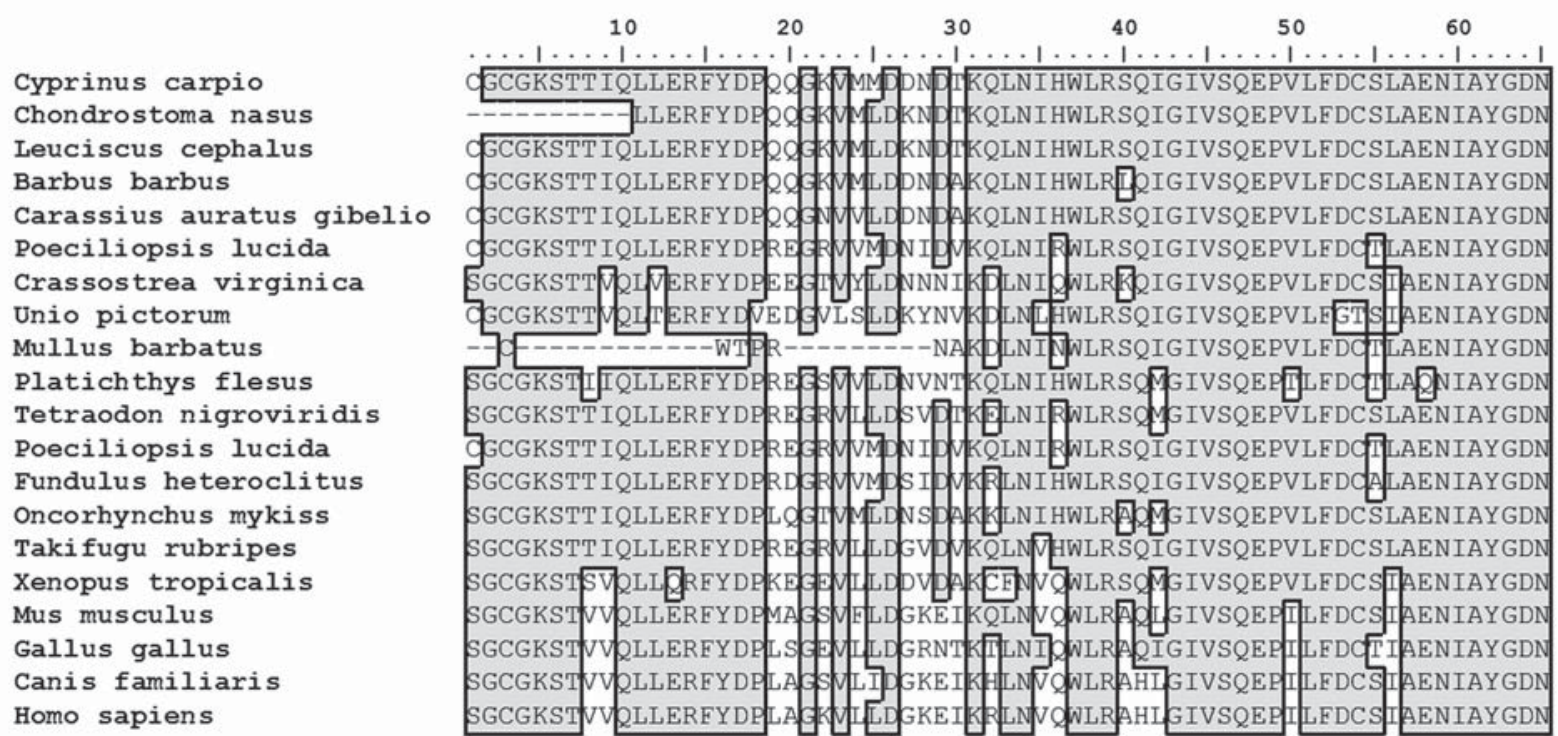

Figure 1 Multiple sequence alignment of all Pgp (Abcb1) sequences obtained in cyprinid fish species with other organisms. Alignment was performed using the Clustal X program. In comparison with common carp sequence, the obtained homologies were in the range of $87 \%$ to $98 \%$ : Chondrostoma nasus (AAX51241) 98\%, Leuciscus cephalus (AAY46403.1) 98\%, Barbus barbus (AAY59423.1) 96\%, Carassius auratus gibelio (AAY59426.1) 96\%, Oncorhynchus mykiss (AAW56424) $95 \%$, Poeciliopsis lucida (AAY82455) 95\%, Takifugu rubripes (AAO20902) 95\%, Mullus barbatus (AY850375) $94 \%$, Platichthys flesus (CAC86600) 93\%, Fundulus heteroclitus (AAD23956) 93\%, Crassostrea virginica (AAP92331) 90\%, Galus galus (XP_418636) 87\%, Homo sapiens (ACF94688) $87 \%$, Canis familiaris (NM 001003215) 86\%, Mus musculus (AAA03243) 85\%, Xenopus tropicalis $85 \%$. 


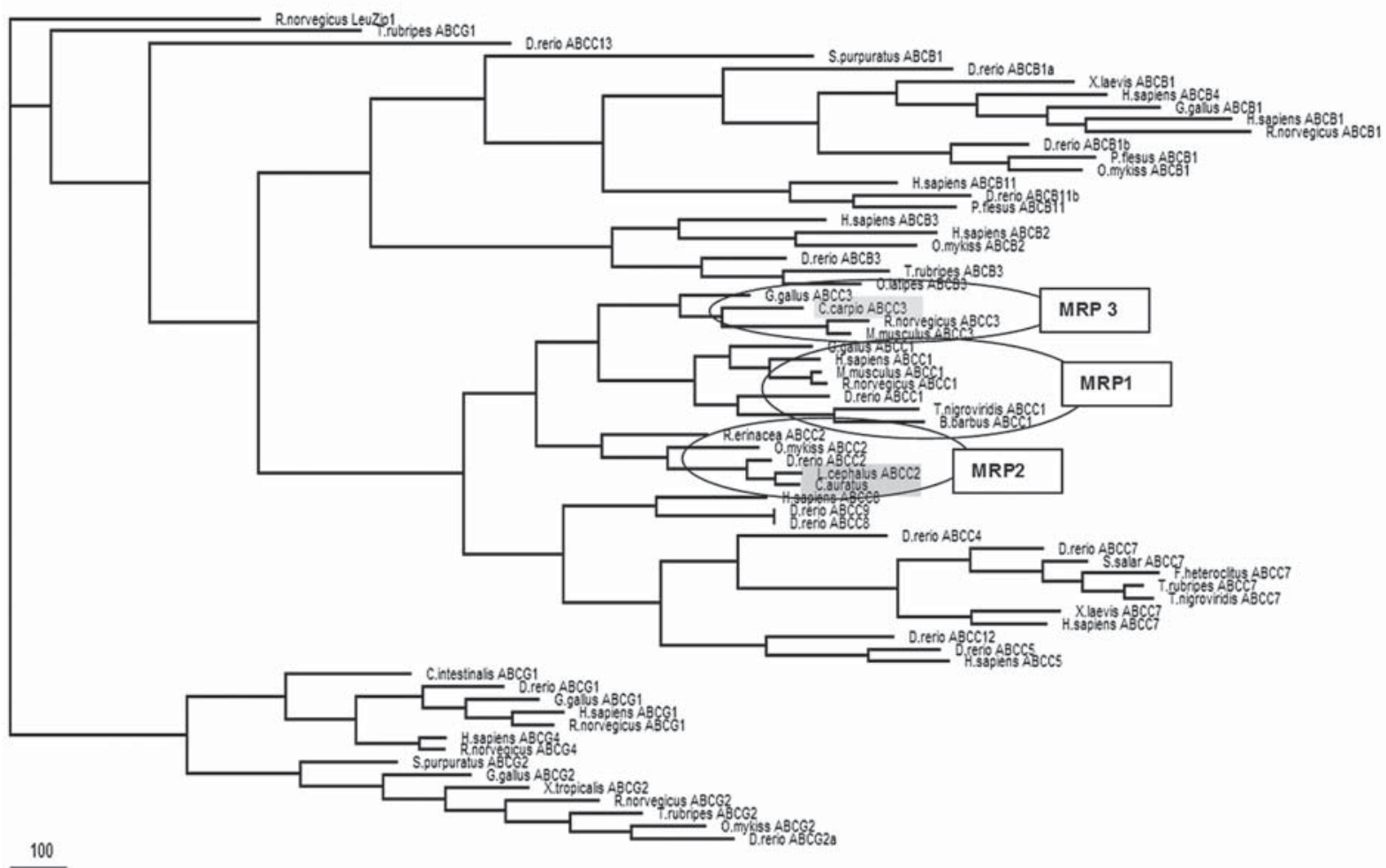

Figure 2 Molecular phylogenetic relationships based on maximum likelihood (ML) analysis of our identified sequences with $A B C B, A B C C$, and $A B C G$-related sequences from other taxonomic groups. ML analysis was done by stepwise addition OF WHAT and replicated 100 times, with each replicate starting with a random input order of sequences in program PAUP* 4.0b10.

\section{Phylogenetic analysis}

The translated sequences were aligned with various $\mathrm{ABC}$ proteins using Clustal X software and phylogenetic trees were generated using the neighbour-joining and maximum likelihood methods. Phylogenetic analysis showed that all identified sequences grouped within the $\mathrm{ABCB}$ or $\mathrm{ABCC}$ subfamily of other organisms (Figure 2).

The analysis of family relationships through short gene and protein sequences from all tested animals clearly showed that the selected primers target highly conserved domains of P-glycoprotein. Consequently, for a more specific phylogenetic analysis, it would be desirable to obtain longer sequences.

\section{Immunochemical detection of Pgp (Abcb1)- and MRP (Abcc)-like proteins in fish liver cells}

As homologous antibodies against teleostean Pgps are not available to date, the C219 monoclonal antibody raised against human Pgp has been used in immunochemical studies to detect a conserved Pgp epitope in aquatic organisms $(28,29)$ within the expected range of Pgps $(130 \mathrm{kDa}$ to $170 \mathrm{kDa})$. Immunoblotting with $\mathrm{C} 219$ confirmed the presence of Pgp-related proteins in the liver of all fish species (Figure 3). Unfortunately, there are still no adequate antibodies for the detection of MRP-related proteins in fish and other aquatic organisms. Both MRPm6 (human anti-MRP1) and $\mathrm{M}_{2} \mathrm{I}-4$ (human anti-MRP2) antibodies failed to recognise MRP-related proteins in the liver of any fish species studied (not shown), additionally supporting their already reported lack of cross-reactivity with non-human/mammalian MRPs (30).

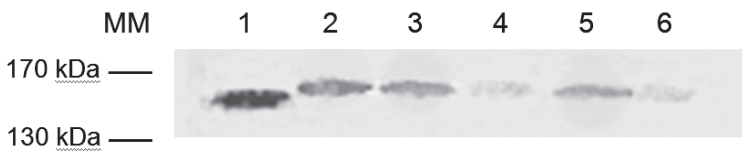

Figure 3 Immunoblot detection of Pgp (Abcb1) in fish liver membrane vesicles (lane $2=$ sneep; lane $3=$ chub; lane $4=$ prussian carp; 5 = barbel; $6=$ common carp; $30 \mu \mathrm{g}$ of membrane vesicle protein per lane). Membrane vesicles from male bovine cortex were used as positive control (lane 1; $10 \mu \mathrm{g}$ of protein per lane). $M M=$ position of molecular mass markers. 


\section{CONCLUSIONS}

Multixenobiotic resistance phenotype expressed in aquatic organisms serves as a defence mechanism that protects these organisms by pumping structurally diverse xenobiotics out of the cells. In analogy to mammalian cells, MXR in aquatic organisms is mainly mediated by transmembrane $\mathrm{ABC}$ proteins. The best-studied $\mathrm{ABC}$ protein in aquatic organisms is MDR P-glycoprotein (Pgp, Abcb1), while recent studies demonstrate the protective role of other types of transport proteins such as MRPs (ABCCs) and the presence of the Mrp-related genes in fish. This study has demonstrated that (a) the MXR defence system in cyprinids, and most probably in teleost fish species in general, is mediated by Pgp (Abcb)and MRP (Abcc)-type of efflux transporters; (b) identified sequences grouped into specific subfamilies of $\mathrm{ABC}$ transport proteins, revealing evolutionary closeness to Abcb1 and Abcc1-3; and (c) reliable immunochemical determination of the expression of Mrp (Abcc) proteins in fish requires development of specific antibodies. These new findings should help to better identify and characterise all proteins possibly involved in MXR in fish.

\section{Acknowledgements}

This work has been supported by the Ministry of Science, Education and Sports of the Republic of Croatia, Project No. 098-0982934-2745.

\section{REFERENCES}

1. Kaufmann SH, Vaux DL. Alterations in the apoptotic machinery and their potential role in anticancer drug resistance. Oncogene 2003;22:7414-30.

2. Townsend DM, Tewl KD. The role of glutathione-Stransferase in anti-cancer drug resistance. Oncogene 2003;22:7369-75.

3. Bates SE. Solving the problem of multidrug resistance: $\mathrm{ABC}$ transporters in clinical oncology. In: Holland IB, Cole SPC, Kuchler K, Higgins $\mathrm{CF}$, editors. $\mathrm{ABC}$ transporters from bacteria to man. San Diego (CA): Academic Press; 2003. p. 359-92.

4. Bard SM. Multixenobiotic resistance as a cellular defence mechanism in aquatic organisms. Aquat Toxicol 2000;48:357-89.

5. Kurelec B. The multixenobiotic resistance mechanism in aquatic organisms. Crit Rev Toxicol 1992;22:23-43.

6. Kurelec B, Smital T, Britvić S, Pivčević B, Krča S, Jelaska D, Balen S, Sauerborn R, Mustajbegović S. Multixenobiotic defence mechanism in aquatic organisms. Period Biol 1997;99:319-28.
7. Smital T, Sauerborn R. Measurement of the activity of multixenobiotic resistance mechanism in the common carp Cyprinus carpio. Mar Environ Res 2002;54:449-53.

8. Smital T, Sauerborn R, Hackenberger KB. Inducibility of the P-glycoprotein transport activity in the marine mussel Mytilus galloprovincialis and the freshwater mussel Dreissena polymorpha. Aquat Toxicol 2003;65:443-65.

9. Xu C, Yong-Tao LC, Kong AT. Induction of Phase I, II and III drug metabolism/transport by xenobiotics. Arch Pharm Res 2005;28:249-68.

10. Kurelec B. A new type of hazardous chemicals: The chemosensitizers of multixenobiotic resistance. Environ Health Persp 1997;105:855-60.

11. Smital T, Luckenbach T, Sauerborn R, Hamdoun AM, Vega RL, Epel D. Emerging contaminats-pesticides, PPCPs, microbial degradation products and natural substances as inhibitors of multixenobiotic defense in aquatic organisms. Mutat Res 2004;552:101-17.

12. Leslie EM, Deeley RG, Cole SPC. Toxicological relevance of the multidrug resistance protein 1, MRP1 (ABCC1) and related transporters. Toxicol 2001;167:3-23.

13. Chan LMS, Lowes S, Hirst B. The ABCs of drug transport in intestine and liver: efflux proteins limiting drug absorption and bioavailability. Eur J Pharm Sci 2004;21:25-51.

14. Dean M, Hamon Y, Chimini G. The human ATP-binding cassette $(\mathrm{ABC})$ transporter superfamily. J Lipid Res 2001;42:1007-17.

15. Sauerborn R, Stupin Polančec D, Žaja R, Smital T. Identification of the multidrug resistance-associated protein (mrp) related gene in red mullet (Mullus barbatus). Mar Environ Res 2004;58:199-204.

16. Žaja R, Sauerborn Klobučar R, Smital T. Detection and functional characterization of Pgp1 (ABCB1) and MRP3 (ABCC3) efflux transporters in the PLHC-1 fish hepatoma cell line. Aquat Toxicol 2007;81:365-76.

17. Žaja R, Munić V, Sauerborn Klobučar R, Ambriović-Ristov A, Smital T. Cloning and molecular characterization of apical efflux transporters (ABCB1, ABCB11 and ABCC2) in rainbow trout (Oncorhynchus mykiss) hepatocytes. Aquat Toxicol 2008;90:322-32.

18. Cai S-Y, Soroka CJ, Ballatory N, Boyer JL. Molecular characterization of a multidrug resistance-associated protein, Mrp2, from the little skate. Am J Physiol Regul Integr Comp Physiol 2003;284:R125-30.

19. Miller DS, Graeff C, Droulle L, Fricker S, Fricker G. Xenobiotic efflux pumps in isolated fish brain capillaries. Am J Physiol Regul Integr Comp Physiol 2002;282:R191-8.

20. Annilo T, Chen ZQ, Shulenin S, Costantino J, Thomas L, Lou H, Stefanov S, Dean M. Evolution of the vertebrate ABC gene family: analysis of gene birth and death. Genomics 2006;88:1-11.

21. Vigano L, Arillo A, Melodia F, Arlati P, Monti C. Biomarker responses in cyprinids of the middle stretch of the River Po, Italy. Environ Toxicol Chem 1998;17:404-41.

22. Flammarion P, Devaux A, Nehls S, Migeon B, Noury P, Garric J. Multibiomarker responses in fish from the Moselle River (France). Ecotoxicol Eviron Safety 2002;51:145-53.

23. Cornwell MM, Gottesman MM, Pastan IH. Increased vinblastine binding to membrane vesicles from multi-drug resistant KB cells. J Biol Chem 1986;261:7921-8.

24. Thompson JD, Gibson TJ, Plewniak F, Jeanmougin F, Higgins DG. The CLUSTAL_X windows interface: Flexible 
strategies for multiple sequence alignment aided by quality analysis tools. Nucleic Acids Res 1997;25:4876-82.

25. Hall TA. BioEdit: a user-friendly biological sequence alignment editor and analysis program for Windows 95/98/ NT. Nucleic Acids Symp Ser 1999;41:95-8.

26. Swofford DL. PAUP*: Phylogenetic analysis using parsimony (and other methods) 4.0 beta. CD-ROM. Sunderland (MA); Sinauer Associates: 2002.

27. National Center for Biotechnology Information (NCBI) BLAST [displayed on 19 May 2010]. Available at http://blast. ncbi.nlm.nih.gov/Blast.cgi.

28. Tutundjian R, Cachot J, Leboulenger F, Minier C. Genetic and immunological characterisation of a multixenobiotic resistance system in the turbot (Scophthalmus maximus).
Comp Biochem Physiol B Biochem Mol Biol 2002;132:46371.

29. Sturm A, Ziemann C, Hirsch-Ernst KI, Segner H. Expression and functional activity of P-glycoprotein in cultured hepatocytes from Oncorhynchus mykiss. Am J Physiol Regul Integr Comp Physiol 2001;281:R1119-26.

30. Scheffer GL, Kool M, Heijn M, de Haas M, Pijnenborg ACLM, Wijnholds J, van Helvoort A, de Jong M, Hooijberg JH, Mo CAAM, van der Linden M, de Vree JML, van der Valk P, Elferink RPJ, Borst P, Scheper RJ. Specific detection of multidrug resistance proteins MRP1, MRP2, MRP3, MRP5, MDR3 P-glycoprotein with a panel of monoclonal antibodies. Cancer Res 2000;60:5269-77. 


\section{Sažetak \\ ODREĐIVANJE PRISUTNOSTI EKOTOKSIKOLOŠKI VAŽNIH Pgp I MRP-PROTEINA U ŠARANKAMA NA GENSKOJ I PROTEINSKOJ RAZINI}

Mehanizam multiksenobiotičke otpornosti (MXR) stanični je obrambeni sustav odgovoran za svojstvo istovremene otpornosti na različite ksenobiotike, koje se očituje smanjenjem akumulacije, odnosno povećanjem izbacivanja potencijalno toksičnih tvari iz stanica vodenih organizama. MXR-mehanizam pokazuje odlike analogne fenomenu istovremene otpornosti na različite lijekove (engl. multidrug resistance, MDR) prvi put dokazanom u tumorskim stanicama. Posredovan je istim $\mathrm{ABC}$ transportnim proteinima kao i MDR. Istraživanja vezana uz MXR vodenih životinja uglavnom su imala težište na određivanju prisutnosti i funkcije P-glikoproteina (Pgp). Budući da se ribe iz reda šaranki često rabe u biomonitoringu slatkovodnih voda, cilj ovog istraživanja bilo je određivanje prisutnosti dvaju glavnih MDR/MXR-tipova proteina Pgp i MRP-tip proteina - u jetri iz pet vrsta šaranki; šarana (Cyprinus carpio), klena (Sqalius cephalus), mrene (Barbus barbus), babuške (Carassius auratus gibelio) i podusta (Chondrostoma nasus). Njihova prisutnost utvrđena je na razini mRNA te na proteinskoj razini. Različiti parovi početnica dizajnirani su kako bi se identificirali homologni fragmenti gena sličnih MXR-u. Detekcija na razini proteina napravljena je putem Western blot analize s pomoću specifičnih monoklonskih protutijela proizvedenih da prepoznaju konzervirane epitope; Pgp (C219), MRP1 (MRPm6) ili MRP2 (M2I-4) u sisavaca. Transkripti obaju ključnih MXR-transportera identificirani su u svim jedinkama, a napravljena je i filogenetska analiza dobivenih sekvenci. Imunokemijskom detekcijom s protutijelima sisavaca nismo uspjeli detektirati prisutnost MRP-proteina, dok je Pgp-ekspresija potvrđena u svih pet vrsta šaranki. Nove spoznaje da je za MXRmehanizam zaslužno više transportnih proteina zasigurno će pridonijeti potpunijoj karakterizaciji MXR-a kao integralnog dijela detoksikacijskog, odnosno temeljnog obrambenog sustava vodenih organizama te njegovoj znanstvenoj afirmaciji kao vjerodostojnog pokazatelja kvalitete okoliša.

KLJUČNE RIJEČI: ABC-proteini, filogenetička analiza, mehanizam multiksenobiotičke otpornosti (MXR), vodeni organizmi, Western blot analiza

\section{CORRESPONDING AUTHOR:}

Dr. Roberta Sauerborn Klobučar

Laboratory for Molecular Ecotoxicology

Division for Marine and Environmental Research

Ruđer Bošković Institute

Bijenička cesta 54

10001 Zagreb, Croatia

E-mail: rsauer@irb.hr 